\title{
Cognitive Processes of Using Representational Form in Mathematical Modeling Based on Gender Differences
}

\author{
Elika Kurniadi*, Novita Sari, Darmawijoyo \\ Program Studi Pendidikan Matematika, Universitas Sriwijaya, Indonesia \\ *elikakurniadi@fkip.unsri.ac.id
}

\begin{abstract}
The process of thinking in formulating a mathematical model requires cognitive processes. In learning mathematics, one of the factors that influence mathematics ability is gender differences. This research explores and provides an overview of the cognitive processes, especially using the representational form in mathematical modeling regarding gender differences. The type of research used is descriptive exploratory with a qualitative approach. The research subjects were 36 pre-service teachers in the mathematics education study program, consists of 18 males and 18 females. The instruments were a written test and an interview guide sheet. The result shows that males get higher percentages than females to answer the representational problem correctly. In conclusion, both males and females solve the graph problem using representative form through three components of the cognitive process. The first and second component, namely knowing and applying, shows the same behavior: retrieving the information from the mathematical problem and displaying the information into the graph. For the third component, reasoning also offers the same behavior because the truth of the graph that justifies refers to the mathematical properties. The study implies that it might be the same treatment for males and females to improve representational form regarding the components of cognitive process, namely, knowing, applying, and reasoning.

Keywords: cognitive process, gender, mathematical modeling
\end{abstract}

Received: June 8, 2021 / Accepted: July 21, 2021 / Published Online: July 23, 2021

\section{Introduction}

In society and almost every sector, mathematical models are used to control, monitor, design, and predict every problem. The problem as a real-world problem cannot be solved with mathematics before the problem is turned into the mathematical language in the form of mathematical models (Hartono, 2020; Kurniadi, Darmawijoyo, \&Pratiwi, 2019). This process of transform real-world problems become mathematical problems is called mathematical modeling as one of the steps to solve mathematical problems (Blum \& Leiß, 2007; Ferri, 2007). The activity of mathematizing real-world problems is known as a mathematical process (De Lange, 2006; Blum \& Niss, 1991). Mathematical modeling is characterized as a cyclical process in which real-world problems are turned into mathematical language, solved using symbolic, and the solutions tested back to real life (Haines \& Crouch, 2007). The 
modeling process starts with a simplified version of the problem by identifying key components of the model and formulating the mathematical model using variables and mathematical expressions. In this activity, the process of thinking in formulating a mathematical model requires cognitive processes.

Cognitive processes are described as the mental processes of an individual which relate particular mental states (such as beliefs, desires, and intention) and understanding information that involves abstraction or concretization (Montague, Krawec, Enders, \& Dietz, 2014). In other words, cognitive processes are defined as processes comprising knowledge, expertise, or learning. Montague (2000) states that some cognitive processes are reading, paraphrasing, visualizing, hypothesizing, estimating, computing, and checking. In Ferri (2006), cognitive processes contain six components: mathematical communication, representational forms, mathematical problem solving, mathematical argumentation, modeling, and technical abilities and skills. One of the components, using a representational form, will be discussed in this study.

Mathematical representation is one of the important skills to be mastered. The ability of mathematical representation is the student's expertise in generating mathematical ideas, namely in the form of meanings, explanations, problems, and so on, to convey the results of their work specifically as a form of student thinking to find solutions to the problems they are facing (Huda, Musdi, \& Nari, 2019). The importance of mathematical representations can be seen from the representation standards set by NCTM. NCTM stipulates that learning programs from pre-kindergarten to grade 12 should enable students to (1) create and use representations to organize, record, and communicate mathematical ideas; (2) select, apply, and translate mathematical representations to solve problems; and (3) using representation to model and interpret physical, social, and mathematical phenomena (NCTM, 2000). In learning mathematics, students sometimes experience difficulties and guide them to use representation form to solve the problem. Therefore, a pre-service teacher must have representation skills to foster representation skills in students.

In addition, one of the factors that influence mathematics ability is gender differences. Gender differences can lead to differences in the psychiatric learning of students so that males and females have many differences in learning mathematics (Keitel, 1998). In line with Fuad (2016), it is said that gender, social, and cultural dimensions are very powerfully interacting in the conceptualization of mathematics educations. If the same mathematical problem is given to several individuals, different solutions will be obtained. The reason is the different 
mathematical representation abilities of students in solving problems. What can lead to differences in students' mathematical representations is gender differences. Male is better in visual-spatial abilities and females to have higher verbal abilities (Umaroh \& Pujiastuti, 2000).

From research by Umaroh and Pujiastuti (2000), there are differences in visual and symbolic representation between males and females. Males can represent visuals by making pictures correctly, while females have not been able to represent them in images. Females can use mathematical equations or models correctly for symbolic representation skills, while males still experience errors in using mathematical symbols. For verbal representation skills, although females lacked confidence in answering questions, males and females had represented written words or texts well by answering questions correctly and re-expressing their work steps clearly. The research results by Umaroh and Pujiastuti (2000) also show that in terms of using verbal representations through written texts, females use them more often than males.

According to the explanations above, the researchers desire to explore and provide an overview of prospective teachers' cognitive processes especially using the representational form in mathematical modeling regarding the gender differences. Therefore, the research question is How does the cognitive process especially using the representational form (graph problem) in mathematical modeling, regarding the gender differences of pre-service teachers mathematics?

\section{Method}

The type of research used is descriptive exploratory with a qualitative approach (Sugiyono, 2016). The purpose is to explore and provide an overview of the cognitive processes especially using the representational form in mathematical modeling regarding gender differences. The research subjects were 36 pre-service teachers in mathematics education program study, consists of 18 males and 18 females. The instruments were a written test and an interview guide sheet. The researcher gives three mathematical modeling problems, but in this paper, we only show one mathematical modeling problem related to the representational form, especially about the graph. The written test question asked the relationship between time/season and number of zoo visitors, and the task is taken by National Educational Panel Study (NEPS) Project. The researcher uses this question because 
it has been validated to assess mathematical modeling, especially the representational aspect, in line with this research.

In this sample item, pre-service teachers need to identify a certain graph representing the given description of the particular relationship. Therefore, they have to understand some properties of graphs, such as slope, minimum point, and maximum point with respect to different representational forms. So, this question is used to explore the cognitive processes especially using the representational form in mathematical modeling with pre-service mathematics teachers.

\section{Mathematical modeling problem about representational form (graph)}

In the summertime, the Atown-Zoo is visited by more people than in winter. However, this year, a brown bear was born in October, which attracted a lot of visitors due to its cuteness. Which of the following graphs correctly displays the number of visitors at the Atown-Zoo?

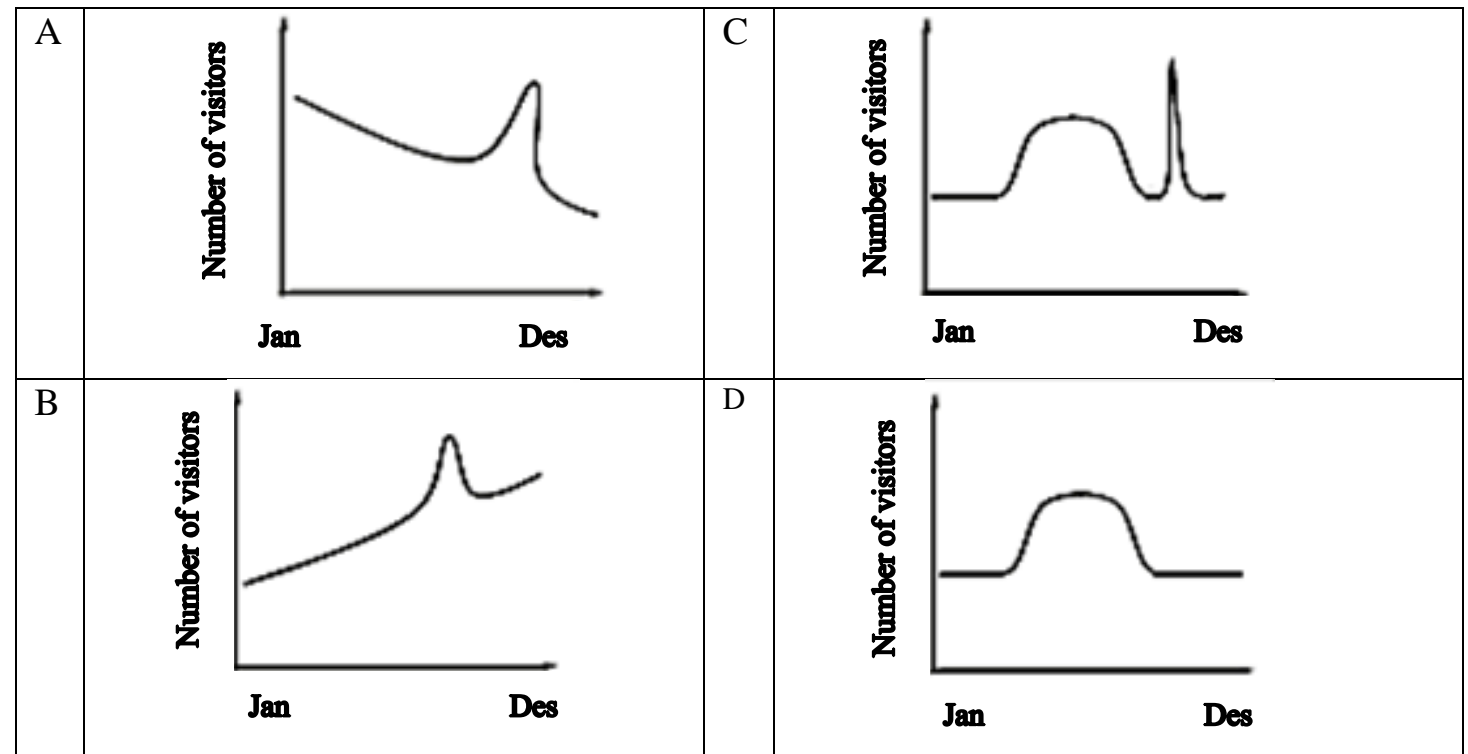

Figure 1. Sample item (Neuman et al, 2013)

The data collection procedure included a mathematics modeling test and interview. There are five males, and five females interviewed to know more about their answers to the problem. For data analysis, transcribed videotape and interview sessions were coded to identify the cognitive processes in mathematical modeling for their individual work. To ensure coding reliability, the researchers coded the data by sharing and discussing individual codings with each other until resolving all disagreements (Strauss \& Corbin, 1990). As the 
basis for the data analysis, we used indicators of the cognitive processes in the mathematical modeling process in this research are presented in Table 1 (Kemdikbud, 2014).

Table 1. Cognitive process in mathematical modeling

\begin{tabular}{lll}
\hline \multicolumn{1}{c}{ Cognitive Process } & & \multicolumn{1}{c}{ Behaviour } \\
\hline Knowing & - & Recall definition, properties and notation \\
& - & Recognize mathematical objects, shapes and expression \\
& - & Retrieve the information from the mathematical problem \\
Applying & - & Use measuring instruments appropriately \\
& - & Select the appropriate strategy or method \\
& - & Display mathematical information and data in Table, Diagram, Graph, etc \\
Reasoning & - & Select equivalent representation for given mathematical relationship \\
& - & Compose the geometric figures to simplify in solving the given problem \\
& - & Create connection and link the different elements between related \\
& & mathematical ideas \\
& & Justify for the truth or falsity refers to mathematical results/properties \\
\hline
\end{tabular}

\section{Results}

The mathematical problem in the instrument is choosing the correct graph based on the situation of the problem. From the situation problem about the visitor of the Atown zoo, we know that 1) more visitors in the summertime rather than winter and 2) This year, a brown bear was born in October which attracted many visitors. The instrument item displayed four optional graphs as follows.

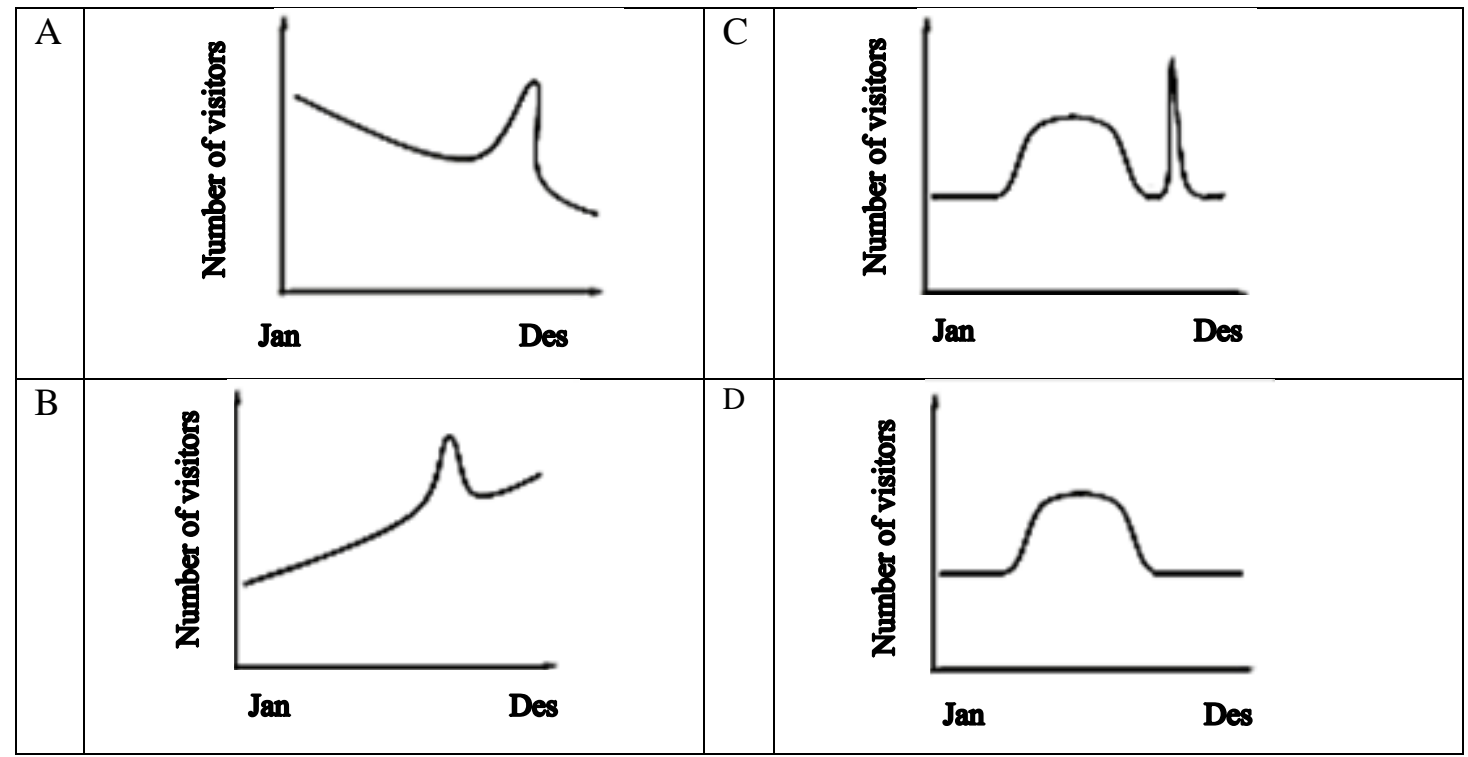

Figure 2. Optional graph 
The following table shows the result of answer from the research subject based on gender differences.

Table 2. The result of the answer

\begin{tabular}{ccccc}
\hline Gender & \multicolumn{4}{c}{ Optional Graph } \\
\cline { 2 - 5 } & $\mathrm{A}$ & $\mathrm{B}$ & $\mathrm{C}$ & $\mathrm{D}$ \\
& \multicolumn{4}{c}{ In percentages (\%) } \\
Male & 5.55 & 27.77 & 66.68 & 0 \\
Female & 33.33 & 16.66 & 44.46 & 5.55 \\
\hline
\end{tabular}

From the table above, we can see that males have the higher percentage to choose the correct graph (graph C). The other interesting point is that $33.33 \%$ of females choose option A, which is an incorrect graph. In contrast, only one of 18 males had chosen option A. The researcher makes a below table to show more detail about the cognitive process in mathematical modeling from the graph of $\mathrm{A}$ and $\mathrm{C}$ based on the gender difference.

Table 3. Cognitive process in mathematical modeling based the gender differences

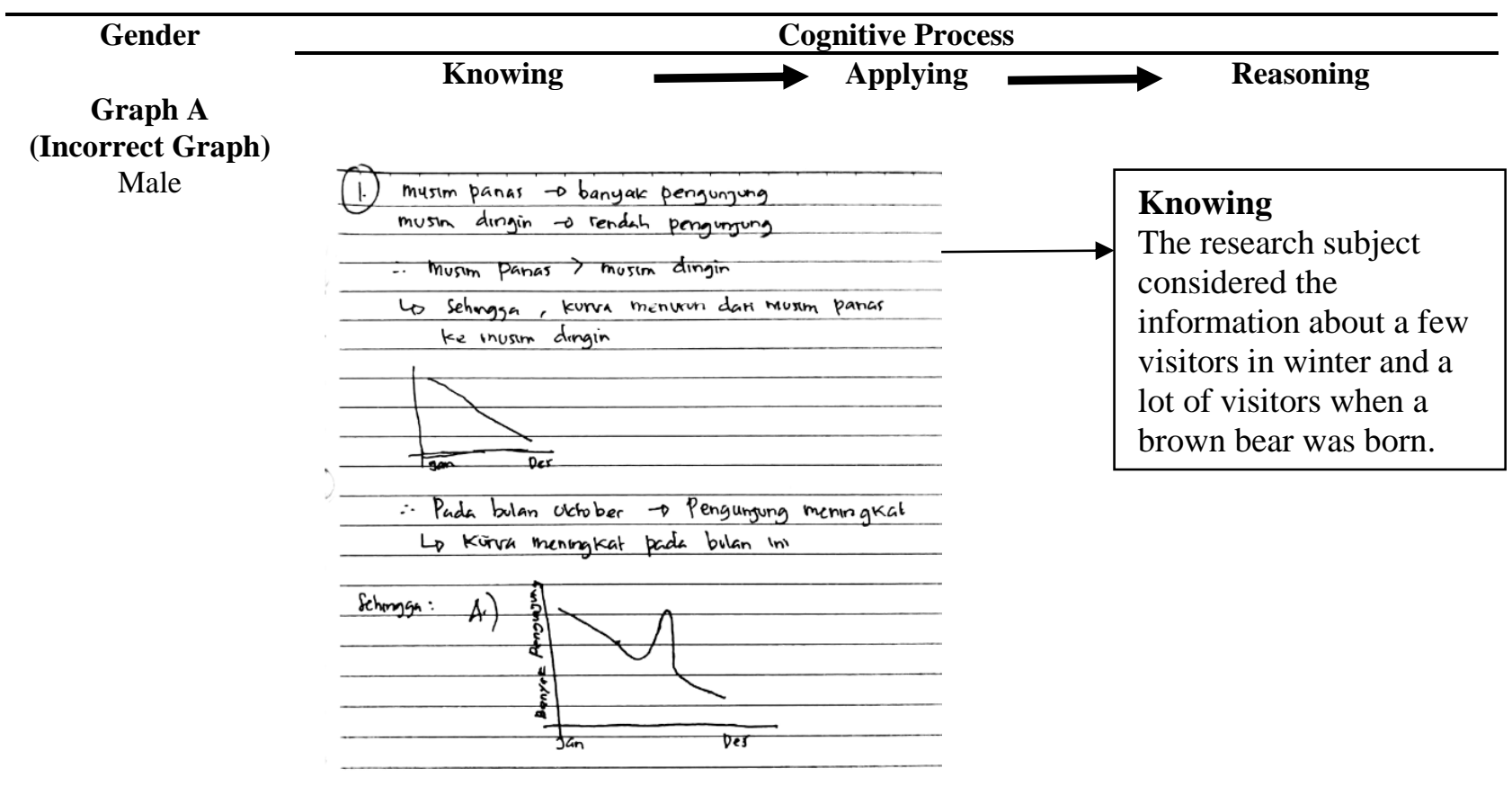

Figure 3. Male work for graph A

According to the interview, the research subject did not realize that the graph's starting point and ending point is the winter season means that it should be a few visitors. The research subject thought that the important thing is the maximum point of the graph is that in October without considering other properties of the global graphic of the zoo visitor for one year. 


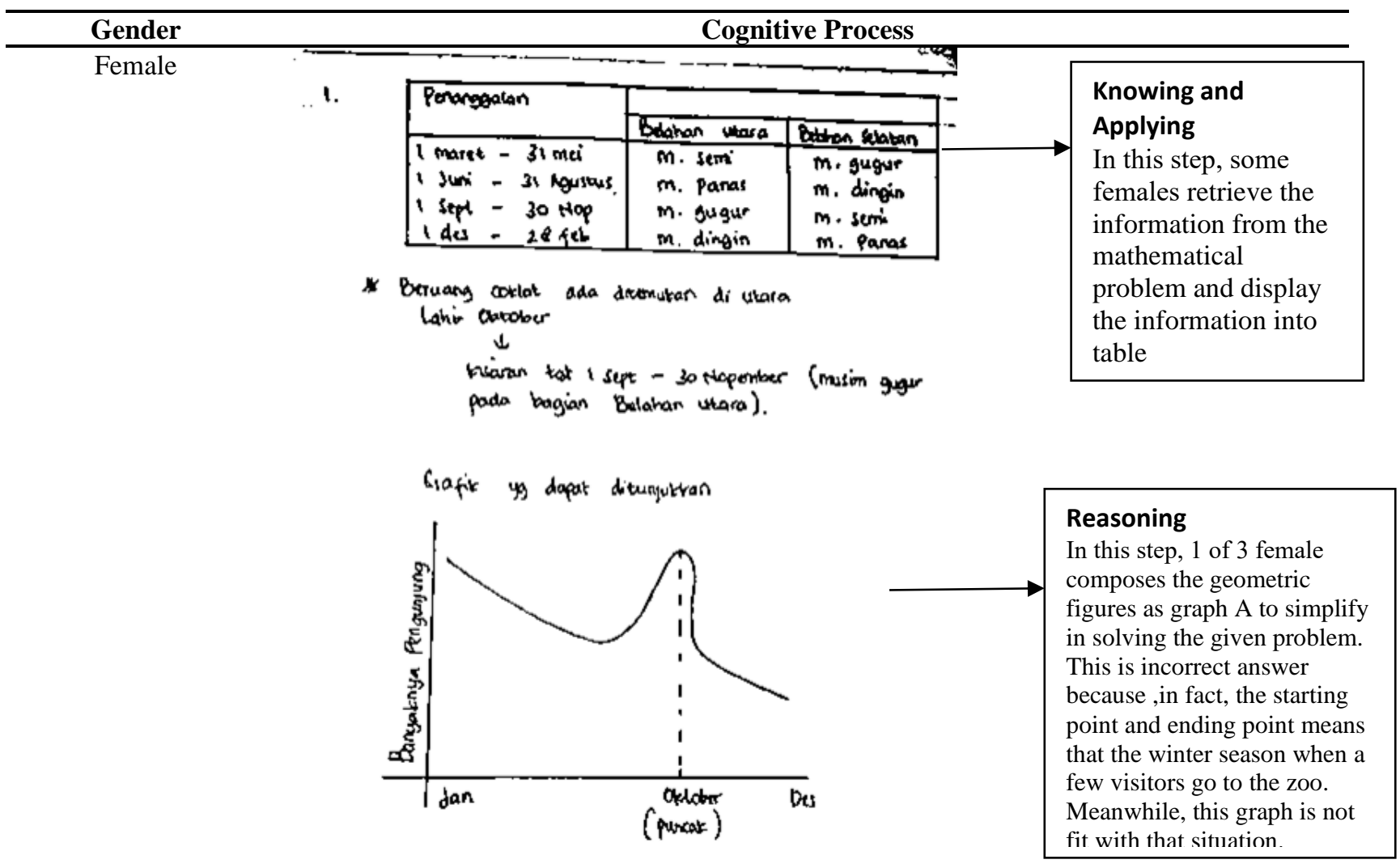

Figure 4. Female work for graph A

According to the interview, the research subject starts with knowing the information of the problem. She generated the table to shows the time of each season; spring, summer, autumn, and winter. The primary consideration is only the time of the bears' born which is October (autumn). Therefore, she thought that then the maximum point of the graph is that in October.

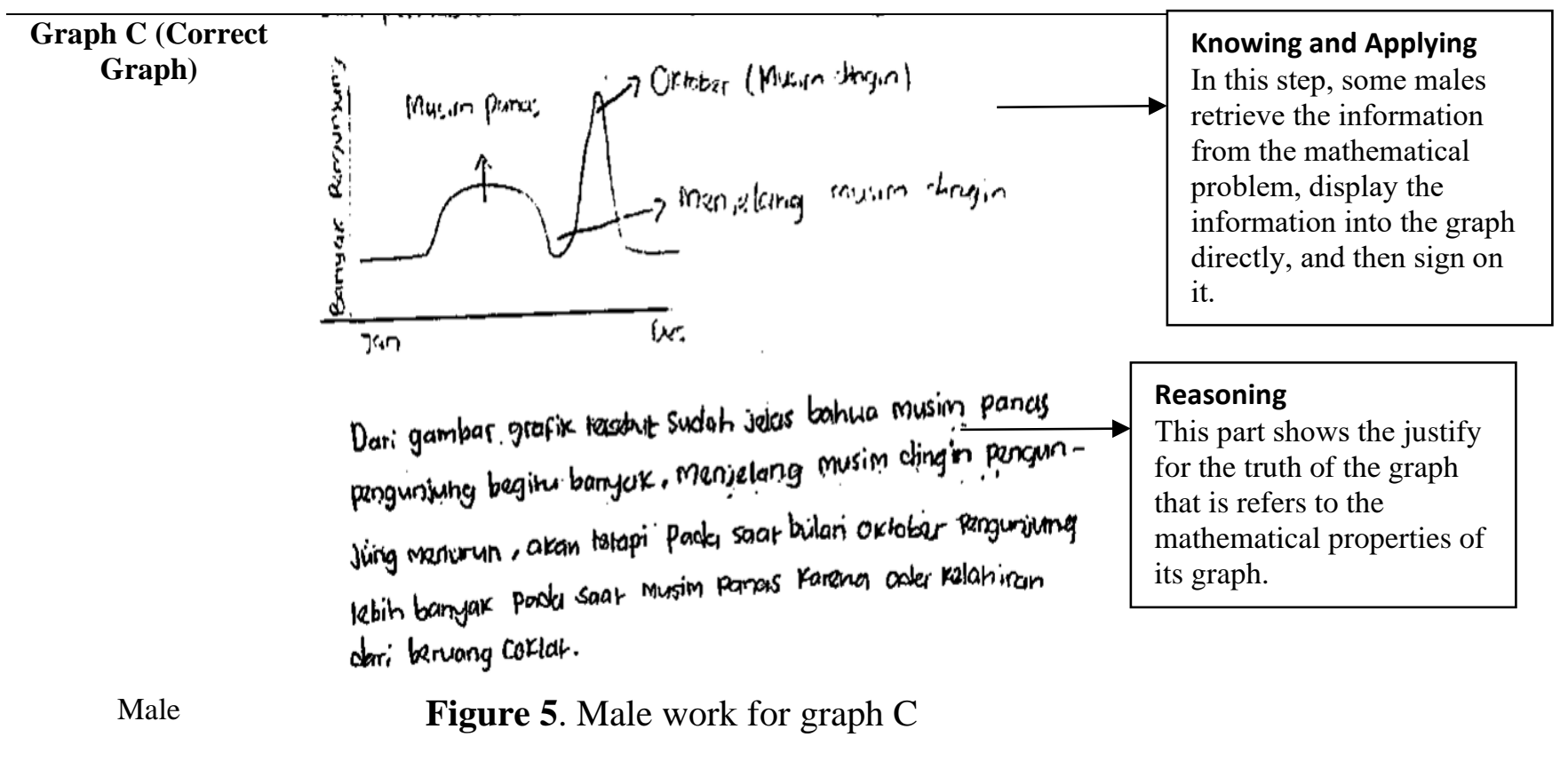


Gender

Female

\section{Cognitive Process}

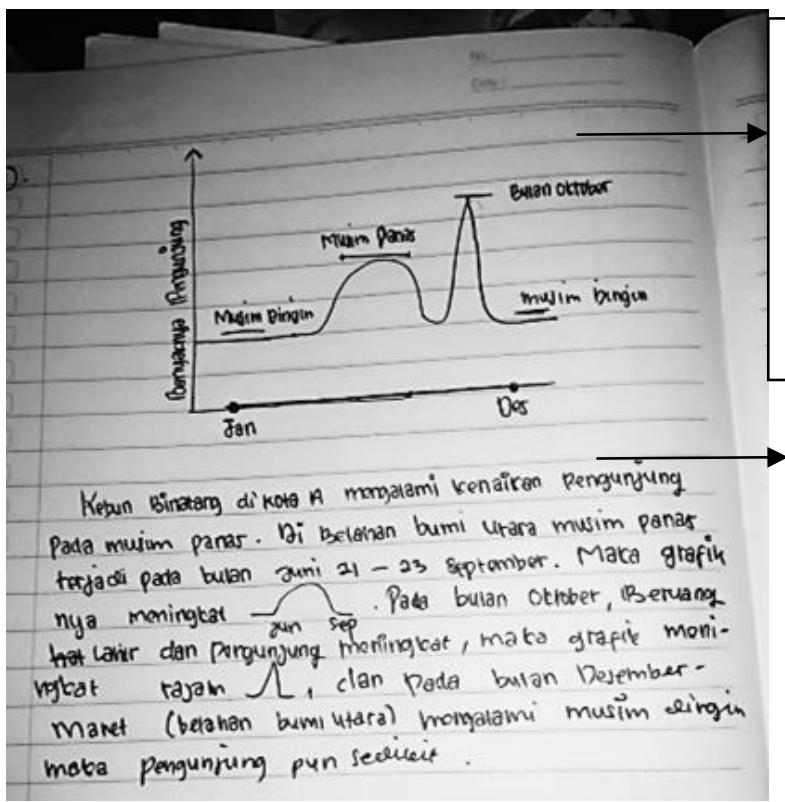

Knowing and Applying

In this step, some males retrieve the information from the mathematical problem, display the information into the graph directly, and then sign on it.

\section{Reasoning}

This part shows the justify for the truth of the graph that is refers to the mathematical properties of its graph.

Figure 6. Female work for graph C

Based on figure 6, we can see the appropriate cognitive process in mathematical modeling. Both males and females could overcome the three processes that are; knowing, applying, and reasoning. The researcher interviewed to make sure their answer. It is a short transcript:

$\begin{array}{ll}\begin{array}{l}\text { Researcher } \\ \text { Subject }\end{array} & : \text { Can you explain your work? } \\ \text { (female) } & : \text { First, I look the optional graph; try to know what it is. } \\ & \text { Then, I understand the problem about the relation of } \\ & \text { Time and number of visitors. From the time, I know } \\ & \text { that more visitor in summer than winter and for this } \\ & \text { year, a bear born in October, and most people want to } \\ & \text { see it. Therefore, the graph has two maximum points } \\ & \text { that are in summer and October. }\end{array}$

The interesting point in this transcript that is female has more consideration with the optional graph in the problem. Meanwhile, males only focus on the situation of the problem. 


\section{Discussion}

According to the result above, from graph $\mathrm{C}$, we can see that males and females execute the three-phase cognitive process in mathematical modeling, namely knowing, applying, and reasoning. However, for males and females made a mistake for choosing the correct graph, they overlooked the phase of cognitive process, for instance, male-only show the knowing aspect, and for female did the wrong in reasoning when they show the behavior is that decompose the geometric figures to simplify in solving the given problem. Male and female in doing the thinking process mean doing the mental activity. Mental activity meant is the activity of receiving, processing, concluding, and extracting information from memory. Process This mentality is known as how someone thinks or is termed cognition (Maaß, 2006). The analysis of the findings from this study indicated that male and female pre-service mathematics teachers showed similar approaches when solving the modeling task about graph problems. In general, their solution consisted of a single cycle of the modeling process. This finding is consistent with Berry (2002), who found most students gave that simple solution approaches and analyzing or clarifying process was spent in less time.

According to Ferri (2010), activities in mathematical modeling require cognitive activity. From the study result, cognitive activity in composing modeling mathematics is through stages from understanding context to validating the solved model. Related to the cognitive processes in mathematical modeling process in this research, the modeling activities for male and female can be grouped as follow: 1) Knowing is related to the step of constructing and simplifying/structuring, 2) Applying is related to the step of mathematizing and working mathematically, and 3)Reasoning is related to the step of interpreting, validating and exposing (Blum \& Leiß, 2007; Blum \& Niss, 1991).

Based on Stillman and Brown (2014), students' inability to make mathematical models will be related to students' failure to apply mathematics relevant to real problems. It also applies if students can make mathematical models, meaning that students can apply mathematics that is relevant to real problems. In mathematical modeling, creativity, fluency, flexibility, and novelty are needed to face an increasingly complex, challenging life (Riyanto et al., 2019). Therefore, students often create various mathematical models along with the creativity, fluency, flexibility, and novelty possessed by students. Based on the results of research that shows female students are better able to plan completion than male students, this is in line with the previous study (Wei et al., 2012) that the advantage of female students in solving arithmetic may be due to the excess of female students in language processing rather 
than basic numerical processing and the research showed that gender differences in verbal processing have implications for the way students work in arithmetic. In addition, in making mathematical modeling, critical thinking skills and good metacognitive development are needed to help students reflect on the answers obtained.

One can compile the modeling not to follow the modeling scheme (Blum \& Leiß, 2007). Male and female in modeling, the problem mathematics will try to do according to the cognition it has. The thing this is because someone in learning and processing information has a way different. According to Maßß (2006), the thought process in mathematical modeling is a description of the thought process that begins with understanding the task, simplifying/structuring the task, mathematizing, working mathematically, interpreting, up to validating based on mathematical modeling routes. Each stage of the modeling route has its cognitive abilities. Regarding gender differences, males have better mathematical abilities than females. This finding is consistent with Krutetski's statement that men have better mathematical than women, and this difference is not apparent at the primary school level but becomes more apparent at a higher school level (Krutetski, 1976).

\section{Conclusion}

It can be concluded that the cognitive process of using the representational form in mathematical modeling for males and females shows different results. In this subject research, more males can answer the graph problem correctly rather than females. Even females have the same mistake at the phase reasoning in the cognitive process when they compose the geometric figure to solve the problem. Overall, both males and females solve the graph problem using representational form through three components of the cognitive process. The first and second component, namely knowing and applying, shows the same behavior: retrieving the information from the mathematical problem and displaying the information into the graph. The third component, namely reasoning, also shows the same behavior is that justification for the truth of the graph that is referred to the mathematical properties.

\section{References}

Berry, J. (2002). Developing mathematical modelling skills: The role of CAS. ZDM-The International Journal on Mathematics Education, 34(5), 212-220. https://doi.org/10.1007/BF02655824.

Blum, W., \& Niss, M. (1991). Applied mathematical problem solving, modeling, applications, and links to other subjects - state trends and issues in mathematics instruction. Educational Studies in Mathematics, 22, 37-68. https://doi.org/10.1007/BF00302716. 
Blum, W., \& Leiß, D. (2007). How do students' and teachers deal with modelling problems? In Haines, C. et al. (Eds), Mathematical Modelling: Education, Engineering and Economics. Chichester: Horwood, 222-231. https://doi.org/10.1533/9780857099419.5.221.

De Lange, J. (2006). Mathematical literacy for living from OECD-PISA perspective. Tsukuba Journal of Educational Study in Mathematics, 25(1), 13-35.

Ferri, R.B. (2006). Theoretical and empirical differentiations of phases in the modelling process. Zentralblatt für Didaktik der Mathematik 38, 86-95. https://doi.org/10.1007/BF02655883.

Ferri, R. B. (2007). Personal experiences and extra-mathematical knowledge as an influence factor on modelling routes of pupils. In Pitta-Pantazi, D \& Philippou, G. (Eds): CERME 5 - Proceedings of the Fifth Congress of the European Society for Research in Mathematics Education, 2080-2089.

Ferri, R.B. (2010). On the influence of mathematical thinking styles on learners' modeling behavior. J. Math Didakt, 31, 99-118. https://doi.org/10.1007/s13138-010-0009-8.

Fuad, M. N. (2016). Representasi matematis siswa sma dalam memecahkan masalah persamaan kuadrat ditinjau dari perbedaan gender. Kreano: Jurnal Matematika Kreatif Inovatif, 7(2). 145-152. https://doi.org/10.15294/kreano.v7i2.5854.

Haines C., \& Crouch R. (2007) Mathematical modelling and applications: ability and competence frameworks. In Blum W., Galbraith P. L., Henn H. W., Niss M. (eds.), Modelling and Applications in Mathematics Education. New ICMI Study Series, Vol. 10. Springer, Boston, MA. https://doi.org/10.1007/978-0-387-29822-1_46.

Hartono, Y. (2020). Mathematical modelling in problem solving. Journal of Physics: Conference Series, 1480(1), 012001. https://doi.org/10.1088/1742-6596/1480/1/012001.

Huda, U., Musdi, E., \& Nari, N. (2019). Analisis kemampuan representasi matematis siswa dalam menyelesaikan soal pemecahan masalah matematika. Jurnal TA'DIB, 22(1), 1925. https://doi.org/10.31958/jt.v22i1.1226.

Keitel, C. (1998). Social justice and mathematics education gender, class, ethnicity and the politics of schooling. Berlin: Freie Universität Berlin.

Kemdikbud. (2014). Mathematics cognitive processes. Jakarta: Kemdikbud.

Krutetski,V.A. (1976). The psychology of mathematical abilities in school children. Chicago: The University of Chicago Press.

Kurniadi, E., Darmawijoyo, \& Pratiwi, W.D. (2019). Developing a learning design of mathematical modelling courses on understanding basic concept of mathematical modelling. Journal of Physics: Conference Series, 1480(1), 012033. https://doi.org/10.1088/1742-6596/1480/1/012033.

Maaß, K. (2006). What are modelling competencies? Zentralblatt für Didaktik der Mathematik, 38, 113-142. https://doi.org/10.1007/BF02655885.

Montague, M., Krawec, J., Enders, C., \& Dietz, S. (2014). The effects of cognitive strategy instruction on math problem solving of middle-school students of varying ability. Journal of Educational Psychology, 106(2), 469-481. https://doi.org/10.1037/a0035176.

Montague, M., Warger, C., \& Morgan, T. H. (2000). Solve it! Strategy instruction to improve mathematical problem solving. Learning Disabilities Research \& Practice, 15(2), 110 116. https://doi.org/10.1207/SLDRP1502 7.

NCTM. (2000). Principles and standards for school mathematics. Virginia: NCTM.

Neumann, I., Duchhardt, C., Grüßing, M., Heinze, A., Knopp, E., \& Ehmke, T. (2013). Modeling and assessing mathematical competence over the life span. Journal for educational research online, 5(2), 80-109. 
Riyanto, B., Zulkardi, Putri, R. I. I., \& Darmawijoyo. (2019). Senior high school mathematics learning through mathematics modeling approach. Journal on Mathematics Education, 10(3), 425-444. https://doi.org/10.22342/jme.10.3.8746.425-444.

Umaroh, U., \& Pujiastuti, H. (2020). Analisis kemampuan representasi matematis siswa dalam mengerjakan soal PISA ditinjau dari perbedaan gender. Jurnal Pendidikan Matematika Raflesia, 5(2), 40-53.

Stillman, G., \& Brown, J. P. (2014). Evidence of implemented anticipation in mathematising by beginning modellers. Mathematics Education Research Journal, 26(4), 763-789. https://doi.org/10.1007/s13394-014-0119-6.

Strauss, A., \& Corbin, J. M. (1990). Basics of qualitative research: Grounded theory procedures and techniques. Thousand Oaks, CA: Sage Publications, Inc.

Sugiyono. (2016). Metode penelitian kuantitatif, kualitatif dan R \& D. Bandung: Alfabeta.

Wei, W., Lu, H., Zhao, H., Chen, C., Dong, Q., \& Zhou, X. (2012). Gender differences in children's arithmetic performance are accounted for by gender differences in language abilities.

Psychological

Science,

23(3),

$320-330$.

https://doi.org/10.1177/0956797611427168. 